\title{
Mn labelling of living oysters: Artificial and natural cathodoluminescence analyses as a tool for age and growth rate determination of $C$. gigas (Thunberg, 1793) shells
}

\author{
Franck Lartaud $^{\mathbf{a}, \mathbf{b},{ }^{*}, \text { Marc de Rafelis }^{\mathbf{a}} \text {, Michel Ropert }}{ }^{\mathbf{c}}$, Laurent Emmanuel ${ }^{\mathbf{a}}$, Philippe Geairon $^{\mathbf{d}}$ and \\ Maurice Renard ${ }^{\mathrm{a}}$
}

\author{
a UPMC Univ Paris 06, UMR 7193 ISTeP, Laboratoire Biominéralisations et Environnements sédimentaires, case \\ postale 116, 4 place Jussieu, 75252 Paris cedex 05, France \\ IUEM-UBO, UMR CNRS 6539, Lab. Sciences de I'Environnement Marin (LEMAR), Technopôle Brest-Iroise, \\ Place N. Copernic, 29280 Plouzané, France \\ ${ }^{c}$ Ifremer, Laboratoire Environnement Ressource de Normandie, Avenue du Général de Gaulle, BP 32, 14520 \\ Port-en-Bessin, France \\ d Ifremer, Laboratoire Environnement Ressource des Pertuis Charentais, Avenue de Mus de loup, $17390 \mathrm{La}$ \\ Tremblade, France \\ *: Corresponding author : Franck Lartaud, email address : franck.lartaud@obs-banyuls.fr
}

\begin{abstract}
:
We developed a growth model for Crassostrea gigas oyster shells based on the use of in situ temporal manganese markings to calibrate natural cathodoluminescence $(C L)$ changes in the shell hinge sections. A $30 \mathrm{~min}$ to 4 -h exposure period with $\mathrm{Mn}^{2+}\left(90-120 \mathrm{mg} \mathrm{I}^{-1}\right)$ was sufficient to create a detectable mark in the shells. This makes the $\mathrm{Mn}^{2+}$ markings the fastest mollusc shells marking technique to date. The natural $\mathrm{CL}$ from juvenile and adult shells cultured in four standard shellfishfarming locations along the English Channel and French Atlantic coasts, exhibited a seasonal pattern (maximum $\mathrm{CL}$ intensity occurring during summer periods, minimum $\mathrm{CL}$ intensity occurring during winter). Hydrobiological data recorded at Baie des Veys site allows us to attribute the seawater temperature as the main parameter controlling $\mathrm{CL}$ of shells. Chlorophyll a and seawater manganese concentration were not decisive in the luminescence intensity of the shells. A relationship between oyster hinge growth and the length of shells makes the umbo investigations a promising tool for oyster-farming and/or wild stock assessments. Shell growth varied at spatial and temporal scales (higher growth rates were observed during summer-autumn and lower during the winter period), depending on seawater temperature changes. Sub-monthly $\mathrm{Mn}^{2+}$ markings support the fact that shell deposition can occur under temperatures below $6{ }^{\circ} \mathrm{C}$, which has to be taken into account for both shellfish production and environmental monitoring derived from chemical compositions of the shells. Finally, our results point out the efficiency of age and shell growth rate determination by $\mathrm{CL}$ analysis in further shellfish ecosystem researches.
\end{abstract}

Keywords: Oyster shells; Crassostrea gigas; Manganese markings; Cathodoluminescence; Seasonal growth patterns 


\section{Introduction}

The Crassostrea gigas world production amounted to 4.6 million tons in 2006. In France alone, 116,150 tons were produced in 2006, which represents approximately a global turnover of 325 thousands US dollars (FAO, 2008). Oyster-farming is thus an important economic supply for many countries. Understanding the modulations of shell growth rate appears fundamental for the shellfish farming so does the research for better growth locations as well as the study of life cycle to avoid summer mortality (Samain and McCombie, 2007). Moreover, it is needed to determine age and shell growth rate to assess the proliferation dynamic of wild oyster populations (Meistertzheim, 2008).

Sclerochronology, the zoological counterpart of dendrochronology, allows the determination of ontogenic ages of bivalves (Hudson et al., 1976; Tanabe, 1988; Jones and Quitmyer, 1996; Richardson, 2001). As bivalve shells were formed by incremental growth, the analysis of skeletal growth patterns from different environmental settings, including marine (Jones, 1983; Chauvaud et al., 1998; Schöne et al., 2003; Richardson et al., 2004) and freshwater bivalve mollusks (Checa, 2000; Kaandorp et al., 2003; Schöne et al., 2004; Verrecchia, 2004), provide clues to determine the age and growth rate of the shells. Shell growth varies cyclically and results in the formation of distinct daily (Goodwin et al., 2001; Schöne et al., 2002; Chauvaud et al., 2005), fortnightly (Schöne, et al., 2003; Verrecchia, 2004) and annual growth lines (Jones, 1980; Witbaard et al., 1994; Marchitto et al., 2000). Many bivalves decelerate their shell growth once per year during seasonal temperature extremes, seasonal food scarcity or annual reproduction cycles (Jones, 1983; Richardson, 2001; Schöne and Giere, 2005). Counting growth increments or growth lines can enable precise calendar dating of each shell portion and estimation of ontogenetic age, life span, onset of maturity, etc. In addition, shell carbonate contains valuable information on habitat 
80

changes that occurred during lifetime. For example, shell growth rates may vary with temperature and food supply (Jones et al., 1989; Hawkes et al., 1996; Chauvaud, et al., 1998; Langlet, 2002; Lartaud et al., 2006). Geochemical data (stable carbon and oxygen isotopes, trace and minor element ratios) can also provide proxy data for environmental and physiological conditions (Killingley and Berger, 1979; Lazareth et al., 2003; Gillikin et al., 2005; Lartaud, 2007; Wanamaker et al., 2007).

Traditionally, growth/age model of oysters are obtained using biometric methods such as the volume of each valve (Higuera-Ruiz and Elorza, 2009), the weight index (Higuera-Ruiz and Elorza, 2004), the shell thickness and the length of valve (dorsal-ventral measurements; Alzieu et al., 1982). Another sclerochronological approach consists in a study of the ligamental area of oyster shells where skeletal growth breaks, associated with concave bottoms, correspond to annual growth increments (Lawrence, 1988; Kirby et al., 1998; Kirby, 2001; Lartaud, et al., 2006) or internal growth lines, checks and bands (Richardson et al., 1993). Unfortunately, most of these methods cannot be carried out regularly on living individuals during an aquaculture experiment. Moreover, shell morphology and its use are strongly dependent on environmental parameters and taphonomic history for fossil specimens (Galstoff, 1964; Surge et al., 2001; Higuera-Ruiz and Elorza, 2009). Indeed, external shell chronological markers may be due to artificial phenomena such as predation or storms (Richardson et al., 1980; Lartaud, et al., 2006).

Chemical marking techniques of bivalve shells could be a good alternative to estimate shell growth rate. Using fluorochromes (Day et al., 1995; Sato-Okoshi and Okoshi, 2002; Thébault et al., 2006), strontium (Fujikura et al., 2003) or manganese (Hawkes, et al., 1996; Langlet et al., 2006; Barbin et al., 2008) on living individuals, bright artificial growth lines can be revealed using microscopy. Because incorporation of such chemical elements into calcite lattice is fast (few hours at most), those particular methods provide a high-resolution 
105 chronologic framework, essential for growth rate change measurements or geochemical 106 sampling and analysis (Kirby, et al., 1998; Lartaud, et al., 2006).

107 In the present study, we investigate the growth rate of oysters Crassostrea gigas using

108 the chemical marking technique of shells with manganese chloride. Unlike the work of

109 Langlet et al. (2006) in which oysters were settled in only one restricted and confined area

110 (Thau Lagoon, Hérault, France), we ran our experiments in open marine environments over

111 two years. Oysters (young and adult specimens) have been cultured in four different standard 112 shellfish-farming locations along the Atlantic coast of France and the English Channel 113 between January 2005 and November 2006. During the breeding period, nearly monthly $\mathrm{Mn}^{2+}$ 114 markings provide a well-adapted tool for the growth rate variability to be quantified (winter 115 cessation, seasonal modifications, etc.). Cathodoluminescence microscopy is then used to 116 reveal together natural luminescence of the shells and artificial sharp growth luminescence 117 band related to markings.

\section{Materials and Methods}

\subsection{Experimental growth conditions and sample preparation}

The experiments were carried out at the Institut Français de Recherche pour

124 1'Exploitation de la Mer (IFREMER), in the marine stations of the institute. Oysters were bred 125 in four locations along the English Channel and the Atlantic coasts (Fig. 1): Baie des Veys 126 (Normandy), L'Houmeau marine pond and Marennes-Oléron Bay (Charente-Maritime), and

127 Arcachon basin (Gironde), which represent the main C. gigas French oyster-farming areas. 128 All of these sites present a semi-diurnal tidal regime. The L'Houmeau marine pond 129 corresponds to a very restricted environment $\left(\sim 500 \mathrm{~m}^{2}\right.$ and $1 \mathrm{~m}$ deep), only overrun by 
130 seawater during spring tides (up to 80 tide coefficient). A hydrological survey was carried out

131 at Baie des Veys (site 1) between January 2005 and November 2006 to determine the role of

132 the environmental parameters in the luminescence of shells. Daily measurements of seawater

133 temperature were provided by the IFREMER YSI probe multi-parameter (fixed to the oyster

134 tables). In order to estimate trophic resources potentially available for oysters, total

135 chlorophyll a $\left(\mu \mathrm{g} .1^{-1}\right)$ were sampled fortnightly, directly filtered through Whatman GF/F

136 filters. Seawater samples were collected monthly in polyethylene bottles previously cleaned

137 with nitric acid and washed wish demineralised water rigorously. Manganese content was

138 determined with an inductively coupled plasma-atomic emission spectrometer (ICP-AES)

139 after preconcentrating metals at $\mathrm{pH} 5.5$ using chelex resin. The standard used for the analysis

140 was the IAPSO international standard.

$141 \quad$ Oyster Crassostrea gigas (Thunberg, 1793) spat were sourced from wild broodtstock

142 at the Arcachon basin at the end of January 2005. The size of the shells $(>10 \mathrm{~mm}$ umbo-

143 margin axis) indicated that they came from the summer 2004 pond. Spats were separated in

144 four distinct groups and transplanted in packs to be cultured on oyster tables at the different

145 study locations until autumn 2006 (Table 1). For each breeding location, we used the same

146 chemical marking process as described in Langlet et al. (2006), in the Thau lagoon C. gigas

147 shells experiment. More precisely, complete packs are immersed during 4 hours in a filled

148 tank with seawater (sampled on the site) containing $90 \mathrm{mg} . \mathrm{l}^{-1}$ of manganese chloride

149 tetrahydrate $\left(\mathrm{MnCl}_{2}, 4 \mathrm{H}_{2} \mathrm{O}\right)$. Once marked, the packs were immediately replaced onto the

150 culture tables. The oyster shells were marked almost each month (see Table 2). During the

151 same period, additional packs were placed on each culture tables for reference. Furthermore,

152 other marking experiments were conducted on $C$. gigas oyster shells from Marennes-Oléron

153 bay to test the effect of $\mathrm{Mn}^{2+}$ markings concentration and incubation time (Table 3). 
At the same time, adult specimens ( $>2$ years) were bred and $\mathrm{Mn}^{2+}$ marked on the

155

156

157

158

159

160

161

162

163

164

165

166

167

168

169

170

171

172

173

174

175

176

177

178 oyster tables from Marennes-Oléron Bay and Arcachon basin with a view to investigate the influence of the ontogeny on the CL response of the shells. The adult samples breed on Marennes-Oléron oyster tables were produced from the IFREMER hatchery at La Tremblade, (Charente-Maritime) and transplanted until they were six months old into nursery tanks at Bouin (Fig. 1). In these tanks the spats were fed daily with a diet of micro-algae (Skeletonema costatum) that had been cultured in drill water rich in manganese (see Hussenot and Buchet (1998) and Pirastru (1994)). This supply of manganese internally marks the shells with a manganese spike-during the entire breeding period at Bouin (Lartaud et al., 2009). Those particular conditions greatly differ from the marine natural environments, where seawater shows very low Mn content. Therefore, those two environments are easily discriminated using CL analysis of the hinge area. The spats were then cultured for one year and a half on oyster tables in the Marennes-Oléron bay and placed in Marennes marine ponds until their use in our $\mathrm{Mn}^{2+}$ marking experiment (September 2005 - November 2006). The adults cultured at the Arcachon basin were born during the summer 2002, collected in February 2003, transplanted for one year on oyster tables in the Morbihan Gulf and one additional year on oyster tables in the Arcachon basin before starting our marking protocol (Table $1 \& 2$ ).

Immediately upon collection the oysters were carefully opened in the field by cutting through the adductor muscle avoiding any damage to the hinge area. The flesh was scrapped and removed from the inner surface of the shell valves to avoid any post-mortem carbonate dissolution following the oysters' aerial emersion. Upon return to the laboratory the shells were placed in a $6 \%$ solution of Hydrogen peroxide $\left(\mathrm{H}_{2} \mathrm{O}_{2}\right)$ for 6 hours to remove any epibiota from the outer shell surfaces, washed in $0.15 \mathrm{~N}$ Nitric acid for 20 minutes to dissolve any carbonate based superficial contamination and rinsed in demineralised water ( 5 mins.) The dry left shell valve of each oyster was cut along the maximum growth axis through the middle 
179 of the hinge region to the ventral shell margin (see Fig. 2). Slides of the hinge region were

180 polished with grains of silica carbide and cerium oxide of decreasing size (to $1 \mu \mathrm{m}$ ), to obtain

181 about $100 \mu \mathrm{m}$ thick sections.

182

183

\subsection{Cathodoluminescence analysis}

184

Cathodoluminescence phenomenon results from the interactions between a lightemitting centre (impurity or chemical element) and the atomic environment inside the crystal lattice during excitation by an electron gun (Machel et al., 1991; Barbin and Schvoerer, 1997). In calcite, $\mathrm{CL}$ emission $(\sim 620 \mathrm{~nm})$ is mainly due to the presence of $\mathrm{Mn}^{2+}$ trapped into the lattice during mineral growth (Amieux, 1982; El Ali et al., 1993; de Rafelis et al., 2000). Cold cathode (Cathodyne-OPEA, $15-20 \mathrm{kV}$ and 200 to $400 \mu \mathrm{A} . \mathrm{mm}^{-2}$ under a pressure of 0.05 Torr) observations were made on the foliated calcite of the hinge section (see Fig. 2), since this area

192 contains an ontogenetic record of both oysters' hinge growth and environmental conditions 193 experienced throughout their life (Carriker and Palmer, 1979; Richardson, et al., 1993; Kirby, 194 et al., 1998; Lartaud, et al., 2006). A numerical Nikon D70 (800 ASA) camera was used for 195 luminescence image acquisition with a constant exposure time of 10s. Mounted photographs, 196 providing a detailed panorama of the hinge, were used to generate luminescence spectra by 197 means of JMicrovision software (Roduit, 2006). Luminescence analyses can only be semi198 quantitative, because each thin-section has its own heterogeneity, which make luminescence 199 intensity normalization impossible (Langlet, et al., 2006; Lietard and Pierre, 2008). 200 Luminescence intensity is therefore expressed in arbitrary units (AU). The markings 201 recognition helps us to transform CL spectra along a growth profile into a calendar profile, by 202 counting a constant growth rate between two consecutive markings. 
$\mathrm{Mn}^{2+}$ markings are also used as temporal point of reference to measure shell growth rate. The analysis of growth intervals were conducted on the CL mounted photographs using the image processing software TNPC 4.1 (www.noesisvision.com). Multiple stepwise nonlinear regression analysis (Statgraphics SGS software) was performed to establish the Von

Bertalanffy relationships of oyster hinges from each location. This equation enables the 208 determination of ontogenetic ages from shell lengths: $\mathrm{Lt}=\mathrm{L} \infty\left(1-\mathrm{e}^{-\mathrm{k}(\mathrm{t}-\mathrm{t} 0)}\right)$, where $\mathrm{Lt}$ is the hinge 209 shell length $(\mathrm{mm})$ at time $\mathrm{t}$ (in years), $\mathrm{L} \infty$ the maximum hinge shell length $(\mathrm{mm}), \mathrm{t}_{0}$ the setting size and k a time constant. Furthermore, Baie des Veys shell lengths were measured during each marking dates to test the hinge-shell lengths relationships.

\section{Results}

\subsection{Mn-chemical marking on living oysters}

At the end of the experiment, comparison between the marked and the reference packs shows that chemical marking technique does not produce any significant stress on oysters, mortality remaining low and similar in both populations. To improve that technique, we tried to modify the protocol proposed by Langlet et al (2006) using higher Mn-concentrations and shortening the time of bathing in doped water (Table 3). Again, the oysters have fully supported the treatment (such Mn concentrations are not lethal to individuals) and oyster 223 shells showed recognizable luminescent bands when using CL microscopy. By reducing the 224 tagging time (4 hours down to 30 minutes), Mn-marking becomes one of the fastest mollusc 225 shells marking technique and can then be very useful when site access is problematic, for example during periods of low tides. 
Fifteen juvenile and six adult oyster shells were viewed under CL analysis. The shells exhibit a natural luminescence graded from purple-dark blue to orange colours contrasting with the distinct orange Mn marking induced luminescence (Fig. 3). Even though CL emission from manganese markings varied in a same shell and through different shells (Fig 4), the marking spikes are easily recognizable on the photomicrographs to be used as point of reference for the natural CL changes calibration. Corresponding dates of $\mathrm{Mn}^{2+}$ markings led to attribute a seasonal fluctuation of the CL rhythms, with an alternation of relative bright and dull luminescent zones during summer and winter times respectively (Fig. 3). Although CL 238 absolute values differ following the sample location, this phenomenon is identified for all 239 shells bred on a same site (Fig. 4a,b,c) and for shells from different sites (Fig. 4e,f). In some 240 location, few shells present a trend in the CL signal during growth that can disturb the 241 apparent seasonal cycle (Fig 4e) but which can be easily removed by a simple subtraction of a 242 linear trend. In others, oyster shells exhibit a highly disrupted natural CL (Fig 4d) without any 243 clear relationship with any seasonal pattern. Regarding such shells, manganese markings are 244 essential to establish a calendar scale in the mineralization. Systematically, the CL emission in 245 the younger part of the shells (first months) is too high to be attributed to a winter period as 246 compared with the rest of the hinge which reveals clear seasonal rhythms and is in 247 contradiction with previous work of Barbin (2000). First, those high CL-intensities could be 248 related to the history of breeding. Indeed, some oysters have been bred for few months into 249 nursery tanks, at Bouin, filled with Mn-rich water. Secondly, during the first months of life, 250 the hinge is made of very tight chalky and foliated microstructures. As shown in Figure 3, 251 chalky calcite is always more luminescent than foliated. During digitalization of CL images, 
252 juvenile part of the hinge often shows abnormally high luminescent due to the close of chalky 253 microstructures.

254 Unlike the younger ones, the $\mathrm{Mn}^{2+}$ markings are not always present in the adult shells.

255 Some winter and spring marks do not appear in the hinge CL spectrum of those specimens 256 (Table 2, Fig 5). Nevertheless, as it is described for juvenile shells, the CL spectrum from 257 older specimens shows the same seasonal changes in the luminescence intensity (Fig. 5). The 258 age determination by CL analysis of shells from Marennes-Oléron bay (3 years old) and 259 Arcachon basin (4 years old) is consistent with the life history of these samples (Table 1).

\subsection{Hinge growth rate of $C$. gigas shells}

We observe a significant correlation between Baie des Veys oyster shells and hinge lengths (Fig. 6). According to this relationship shell length can be modelled by hinge growth measurements. So all measures made on oyster's hinge would provide information about shell length variations. Using that technique, no individual biometric measurement is needed during the life of the animal because all the oysters of a same location are marked in one time (the entire pack is immersed in doped Mn-seawater). Post-mortem CL analysis allows the reconstruction of the overall growth history of organisms.

Using precise temporal marks with the manganese markings, our estimations of hinge

271 growth rate display a high shell growth rate during the first year of life for oysters from each 272 shellfish location (daily growth calculations ranged between 36 and $51 \mu \mathrm{m} / \mathrm{d}$, see Table 4). 273 Oyster shells from the most protected environment (L'Houmeau marine pond, site 2) grew 274 faster during the first step of life. Within the second year, a clear difference in shell growth 275 was observed between each location. Oysters from Baie des Veys and Arcachon basin have 276 the highest mean hinge daily growth rate (19 and $17 \mu \mathrm{m} / \mathrm{d}$, respectively), whereas it is lower 
277 for oyster shells from Marennes-Oléron and L'Houmeau marine pond ( 7 and $5 \mu \mathrm{m} / \mathrm{d}$,

278 respectively). A clear slow down is observed after 3 years with only a $4 \mu \mathrm{m} / \mathrm{d}$ hinge mean 279 daily growth rate.

280 Shell growth spatial variations can be pointed out using the Von Bertalanffy growth 281 equation (Fig. 7). Shells from Baie des Veys exhibit the extended maximum of hinge size (L $\infty$ $282=33.245 \mathrm{~mm})$ whereas shells from Marennes-Oléron bay $(\mathrm{L} \infty=12.966 \mathrm{~mm})$ and the 283 protected marine pond from L'Houmeau $(\mathrm{L} \infty=11.793 \mathrm{~mm})$ have the lowest maximum hinge 284 size. We notice a good correlation in the hinge growth between oyster from the same site in 285 Baie des Veys $\left(r^{2}=0.95\right)$, Marennes-Oléron $\left(r^{2}=0.80\right)$ and, to a lesser extent, Arcachon basin $286\left(r^{2}=0.66\right)$. However, hinge growth shows a higher inter-individual variability in the 287 L'Houmeau marine pond $\left(\mathrm{r}^{2}=0.46\right)$. As revealed by the figure 7 , two distinct models seem to 288 have taken place. Marennes-Oléron shells have a low growth rate with a slow-down period 289 which appear earlier in the life of the oysters around 2 years of age. On the contrary, Baie des 290 Veys shells have a higher growth rate and the slowing down takes place later. However, the 291 absence of adult shells at this location can slightly disturb our shell growth rate slow down estimation. Arcachon and L'Houmeau marine pond shells show a mix between these two 293 cases. Those shells have a lower growth rate than in Baie des Veys oysters, but the ontogenic 294 slow-down appears before the oysters turned three.

At a seasonal scale (Fig 8), if we notice a decrease in the shell growth rate during the 296 winter period, no total cessation in the carbonate biomineralization has been encountered 297 between two consecutive markings. Shells from Baie des Veys exhibit a large seasonal 298 change in the hinge growth rate. Maximum shell depositions are observed during summer 299 early autumn period, with peaks until 41 to $55 \mu \mathrm{m} / \mathrm{d}$ in 2005 and 22 to $41 \mu \mathrm{m} / \mathrm{d}$ in 2006 . The 300 lowest growth rates $(\sim 10 \mu \mathrm{m} / \mathrm{d})$ take place in winter (Fig. 8). The shells from other locations 

manganese.

\section{Discussion}

present a less significant (Marennes-Oléron bay, Arcachon basin) or none at all (L'Houmeau marine pond) seasonal fluctuation in the hinge growth rate.

\subsection{Relationship between environmental parameters and intensity of natural luminescence}

Mean seawater temperatures between markings show a clear seasonal range in Baie des Veys (from $6.0 \pm 0.1^{\circ} \mathrm{C}$ in February to $19.1 \pm 0.1^{\circ} \mathrm{C}$ in August, see Table 5). Two annual major phytoplankton blooms are identified by chlorophyll a measurements. One occurs in spring, the other during early autumn. In parallel, no seasonal trend can be deduced from the Mn seawater content analysis, even when the data are compared with those of salinity. A decrease in salinity, for example related to fresh-water runoff, cannot be mentioned.

A correlation matrix between measured seawater environmental parameters (temperature, chlorophyll a and manganese content) and oyster shells properties (hinge growth rate and CL emission) at Baie des Veys (site 1), has been investigated using a principal component analysis (PCA). PCA is used to obtain an overview of the data and identify possible sources, significant correlations (at $p=0.05$ level) are sought. In this test, $69 \%$ of the variability is explained by 5 variables listed hereafter. As described by the correlation matrix of the variables, we can observe significant positive correlations between $\mathrm{CL}$ and seawater temperature $(r=0.511), \mathrm{CL}$ and hinge growth rate $(\mathrm{r}=0.427)$, seawater temperature and hinge growth rate $(r=0.678)$, seawater temperature and chlorophyll a $(r=$ $0.340)$, seawater manganese content and hinge growth rate $(\mathrm{r}=0.531)$. Finally, no significant correlations are observed between CL and chlorophyll a or between CL and seawater 
In the present study, the use of $\mathrm{Mn}^{2+}$ markings of juvenile and adult oyster shells bred 330 in different locations (Baie des Veys, L'Houmeau marine pond, Marennes-Oléron bay and 331 Arcachon basin) allows the identification of a clear seasonal cycle in the natural 332 cathodoluminescence of the hinge. Those results are in agreement with previous observations 333 from Langlet et al. (2006) on C. gigas shells from Thau lagoon (France). As revealed by our 334 experiment, the seasonal fluctuations in oyster hinge CL take place both in protected and open marine environments. Furthermore, no influence of ontogeny seems to act on the CL rhythms, 336 at least throughout the $4^{\text {th }}$ year of life. However, the CL spectrum is occasionally disturbed 337 and the seasonal cyclicity is no longer visible (i.e. shell MAn6-4 from L'Houmeau marine 338 pond, Fig 4d). Langlet et al. (2006) and Barbin et al. (2008) show variations in the natural 339 luminescence intensity of $C$. gigas shells at daily and tidal cycles which clearly overlap the 340 low frequency seasonal cycles. The non-registration of a seasonal cyclicity on CL spectrum of 341 L'Houmeau marine pond shells could be explained by the peculiarities of this environment, 342 such as very low depth, which enhance the exchanges with the atmosphere. For example, 343 winter water temperature can drop below $0^{\circ} \mathrm{C}$ while summer salinity can rises up to 40 PSU.

344 These extreme values do not prevent the growth shell (Fig. 4d) but are probably sufficient to 345 affect the bio-availability of manganese during growth. Thus, in the very confined 346 environments, such as marine ponds, seasonal fluctuations of natural luminescence are not 347 expressed in the shell while a high-frequency cyclicity (tides, showers) is well expressed. 


\subsubsection{Contribution to shellfish ecosystems monitoring}

As noticed by Langlet (2002) for C. gigas shells from the Thau lagoon (south of France), the hinge - shell length relationship observed in the shells from Baie des Veys (north of France) in the present study, proved that growth measurements made on the umbo turns out to be an interesting tool for oyster farming. Shell growth measurements made during the IFREMER - REMORA shellfish program (Fleury et al., 2003) on C. gigas bred at the same sites than those used in this study, show similar spatial and temporal variations than our results about the hinge growth (higher growth rate in Normandy, summer-autumn seasonal peak). The REMORA program consists in a complete aquaculture assessment (mortality, growth, yield breeding, trade quality) of French oyster-farming by quarterly sampling on the field. The study of the hinge area would deliver an alternative method to such aquaculture approach.

\subsubsection{Temporal and spatial variations}

In our study, seasonal changes in the hinge growth rate can be attributed to seawater temperature fluctuations, but not to variations in the food supply. Carbonate shell deposition in oyster species stimulated by seawater temperature have been already reported by Dame (1972), Richardson et al. (1993), Kirby et al. (1998) and Gangnery et al. (2003). Most contrasted seasonal SST locations (i.e. Baie des Veys) generate a higher seasonal change in the shell growth rate than less variable environments (L'Houmeau marine pond). Kirby et al. (1998) pointed out $C$. virginica growth breaks related to water temperature below $10^{\circ} \mathrm{C}$. Our marking-recapture experiment clearly demonstrates that $C$. gigas shell deposition can take place under temperature as low as $6^{\circ}$. Corresponding growth rate of the hinge area of shells 
376 from Baie des Veys is close to $10 \mu \mathrm{m} / \mathrm{d}$ at this time (see Fig. 8). This is consistent with the

377 results from Child and Laing (1998) that showed the tolerance of juvenile Pacific oysters is

378 about three weeks at $3^{\circ} \mathrm{C}$. The existence of a full year mineralization allows the winter

379 temperature to be reconstructed from geochemical analysis of the shells (Wanamaker, et al., 380 2007).

381 The shells from the northern location (Baie des Veys) exhibit the highest growth 382 properties (maximum size and length of steady growth). On the other hand, the southward and 383 most protected site (L'Houmeau marine pond) shows the lowest growth properties. Spatial 384 variations in the hinge growth rate could neither be explained only by seawater temperatures, 385 nor chlorophyll a variations. Oyster flesh growth can be approached by a Dynamic Energy 386 Budget (DEB) model, where forcing variables are temperature and phytoplankton densities 387 (Kooijman, 2000; Pouvreau et al., 2006). However, recent works demonstrated that a single 388 genetic pool placed in different environments could present distinct growth model which 389 could not be assigned by the DEB model (Meistertzheim, 2008). The author concluded to a 390 failure in the present DEB chosen variables, in particular about the food supply estimations. 391 Indeed, a high diversity of the sources of food (phytoplankton, protozoa, micro-zooplancton, 392 bacterial aggregates, detritical organic matter etc.) is now recognized for $C$. gigas. That 393 heterogeneity in the food supply might be taken into account to determine shell growth 394 differences according to the shellfish production areas.

4.3. Role of environmental parameters upon natural CL of shells

The CL oscillations have been related to $\mathrm{Mn}^{2+}$ changes in the shells (Langlet, et al., 399 2006; Barbin, et al., 2008). Mean Mn concentrations are higher in orange areas (15-20 ppm) 400 than in the dull areas (2.5-5 ppm; Langlet, 2002; Lartaud, 2007). Seawater temperature, algal 
401 bloom event and manganese bioavailability to filter feeder and rate of shell deposition are

402

403

404

405

406

407

408

409

410

411

412

413

414

415

416

417

418

422

424

widely recognized as the main factors to control Mn of shells (Hockett et al., 1997; Lewis and Cerrato, 1997; Vander Putten et al., 2000; Lazareth, et al., 2003; Cravo et al., 2004; Langlet, et al., 2006). During markings, $\mathrm{Mn}^{2+}$ addition is about three thousand times more concentrated than natural seawater (Hockett et al., 1997; Barbin et al., 2008; this study). Although the manganese markings point out an uptake in $\mathrm{Mn}^{2+}$-rich water (seawater containing $90 \mathrm{mg} . \mathrm{l}^{-1}$ of Mn chloride tetrahydrate, see Materials and Methods), natural CL of shells are not linked to seawater Mn fluctuations (definitely lesser concentrated, see Table 5). Our results indicate that natural luminescence is mainly controlled by seawater temperature and shell growth rate. Works on growth of inorganic calcite under experimental conditions described a positive correlation between temperature and $\mathrm{Mn}^{2+}$ uptake in the calcite lattice (Dromgoole and Walter, 1990). The rise in temperature affects the incorporation of manganese into calcite, by modifying the distribution coefficient for $\mathrm{Mn}^{2+}\left(\mathrm{D}_{\mathrm{Mn}}\right)$. Although their works were only directed about experimental calcite overgrowth, so difficult to reproduce for biogenic carbonate, Dromgoole and Walter (1990) showed that $D_{M n}$ values ranged from 3 to 11 at $10^{\circ} \mathrm{C}$, and from 8 to 22 at $50^{\circ} \mathrm{C}$. Moreover, the biomineralization processes stimulation by temperature (i.e. rate of shell deposition) increases the rate of $\mathrm{Ca}$ turnover in the oyster mantle (Wheeler, 1992). As the bulk of shell calcium comes from the external medium, $\mathrm{Ca}^{2+}$ is actively transported from the seawater to the extrapallial fluid during shell deposition (Carré et al., 2006). It has been demonstrated that $\mathrm{Mn}^{2+}$ is used as an analogue of $\mathrm{Ca}^{2+}$ in the uptake of cations from the external medium (Markich and Jeffree, 1994). Thus, a rise in water temperature may increase $\mathrm{Mn}^{2+}$ uptake and its transfer to the site of shell mineralization, resulting in higher concentrations in the growth layers. This agrees with the results of Wada and Fujinuki (1976), which showed that the $\mathrm{Mn}^{2+}$ concentration in the extrapallial fluid of $C$. 
425 gigas was higher $(\sim 0.21 \mathrm{ppm})$ during periods of active shell growth than during periods of 426 low growth $(\sim 0.15 \mathrm{ppm})$.

Our measurements show that temperature, shell growth rate, chlorophyll a and $\mathrm{Mn}$ content in seawater can explain about $70 \%$ of the CL signal. Other parameters might affect the CL emission of the shells, such as self-quenching of the organic matrix (Götte and Richter, 2009). Further works have to deal with a better understanding in the cause of natural CL changes in the shells. Marking experiments on shorter periods (i.e. week to sub-daily rather than monthly as used in our study) on specific seasons (summer, winter) will provide an easier comparison between seawater parameters and shell CL.

\section{Conclusion} previously Mn labelled, demonstrated seasonal patterns of natural luminescence that were used to determine the oysters age and establish a chronological scale along the shell hinge sections. These seasonal changes in the CL of shells were recognized in juvenile and adult oysters at four locations along the English Channel and French Atlantic coastal waters, and were mainly attributed to temperature variations. This efficient sclerochronological profile could be used to define the positions for high resolution drilling of samples of shell carbonate

444 for geochemical analysis in order to reconstruct environmental parameters.

The relationship between umbo and shell length provides an efficient tool for oyster-

446 farming and/or wild stock assessments. Shell growth rate variations during ontogeny can be 447 drawn from the post-mortem hinge study. The general growth pattern (seasonality) was driven 448 by temperature. At a monthly time scale, none growth cessation was observed, even in winter 449 when temperatures below $6^{\circ} \mathrm{C}$. 
Thanks to an easy implementation process (efficient within $30 \mathrm{~min}$ ), such $\mathrm{Mn}^{2+}$ marking-recapture experiment, which supplies accurate details about the spatial and temporal oyster shell growth, could be brought into general for shellfish ecosystems studies (e.g. growth performance per oyster farms, improvement in the DEB model, etc.).

\section{Aknowlegments}

This work was financially supported by University Pierre and Marie Curie (Paris 06) via the BQR project "High frequency to very high frequency recordings of environmental changes to climate by biomineralizations" (Marc de Rafelis, project leader). We wish to thank Fabienne Rauflet, Aline Gangnery, Stephane Robert, Danièle Maurer, Florence D’Amico, Marianne Alunno-Bruscia (IFREMER) and Frederic Delbes (UPMC) for field and laboratory assistance. Thank you to Pierre BENOIT (Laboratoire d'Hydrologie) for the seawater ICPAES analyses. We are grateful to Michel Roux and Elisabeth Schein (Univ. Reims) for their helpful advices on the $\mathrm{Mn}^{2+}$ markings and the oyster shell growth.

\section{References}

Alzieu, C., Heral, M., Thibaud, Y., Dardignac, M.J., Feuillet, M., 1982. Influence des peintures antisalissures à base d'organostanniques sur la calcification de la coquille de l'huître Crassostrea gigas. Revue des travaux de l'Institut des pêches maritimes. 45, 100-116.

Amieux, P., 1982. La cathodoluminescence: méthode d'étude sédimentologique des carbonates. Bulletin Centre de Recherche Exploration - Production Elf-Aquitaine 6, 437-483. 
475 Barbin, V., 2000. Cathodoluminescence of Carbonate Shells: Biochemical vs Diagenetic Process. In: Pagel, M., Barbin, V., Blanc, P., Ohnenstetter, D. (Eds.), Cathodoluminescence in Geosciences. Springer Verlag, Berlin, pp. 303-329.

Barbin, V., Schvoerer, M., 1997. Cathodoluminescence and geosciences. Compte Rendus de l'Académie des Siences de Paris 325, 157-169.

Barbin, V., Ramseyer, K., Elfman, M., 2008. Biological record of added manganese in seawater: a new efficient tool to mark in vivo growth lines in the oyster species Crassostrea gigas. Int J Earth Sci 97, 193-199.

Carré, M., Bentaleb, I., Bruguier, O., Ordinola, E., Barret, N.T., Fontugne, M., 2006. Calcification rate influence on trace element concentrations in aragonitic bivalve shells: Evidence and mechanisms. Geochim. Cosmochim. Acta 70, 4906-4920.

Carriker, M.R., Palmer, R.E., 1979. A new mineralized layer in the hinge of the oyster. Science 206, 691-693.

Chauvaud, L., Thouzeau, G., Paulet, Y.M., 1998. Effects of environmental factors on the daily growth rate of Pecten maximus juveniles in the Bay of Brest (France). J. Exp. Mar. Biol. Ecol. 227, 83-111.

Chauvaud, L., Lorrain, A., Dunbar, R.B., Paulet, Y.-M., Thouzeau, G., Jean, F., Guarini, J.M., Mucciarone, D., 2005. Shell of the Great Scallop Pecten maximus as a high frequency archive of paleoenvironmental change. Geochem. Geophys. Geosyst. 6, 134.

Checa, A.G., 2000. A new model for periostracum and shell formation in Unionidae (Bivalvia, Mollusca). Tissue Cell 32, 405-416.

Child, A.R., Laing, I., 1998. Comparative low tolerance of small juvenile European, Ostrea edulis L., and Pacific oysters, Crassostera gigas Thunberg. Aquac. Res. 29, 103-113. 
Cravo, A., Bebianno, M.J., Foster, P., 2004. Partitioning of trace metals between soft tissues and shells of Patella aspera. Environ. Int. 30, 87-98.

Dame, R.F., 1972. The ecological energies of growth, respiration and assimilation in the intertidal American oyster Crassostrea virginica. Mar. Biol. 17, 243-250.

Day, R.W., Williams, M.C., Hawkes, G.P., 1995. A comparison of fluorochromes for marking abalone shells. Marine and Freshwater Research 46, 599-605.

de Rafelis, M., Renard, M., Emmanuel, L., Durlet, C., 2000. Apport de la cathodoluminescence à la connaissance de la spéciation du manganèse dans les carbonates pélagiques. Compte Rendu de l'Académie des Sciences de Paris 330, 391 398.

Dromgoole, E.L., Walter, L.M., 1990. Iron and manganese incorporation into calcite: Effects of growth kinetics, temperature and solution chemistry. Chem Geol 81, 311-336.

El Ali, A., Barbin, V., Calas, G., Cervelle, B., Ramseyer, K., Bouroulec, J., 1993. Mn2+ activated luminescence in dolomite, calcite and magnesite: quantitative determination of manganese site distribution by EPR and CL spectroscopy. Chem Geol 104, 189202.

FAO, 2008. Aquaculture production: quantities 1950-2006. Fishstat plus.

Fleury, P.G., Simone, C., Claude, S., Palvadeau, H., Guilpain, P., D'Amico, F., Le Gall, P., Vercelli, C., Pien, S., 2003. REMORA Résultats des stations NATIONALES Année 2002. IFREMER - Laboratoire Conchylicole de Bretagne, La Trinité/mer, pp. 49.

Fujikura, K., Okoshi, K., Naganuma, T., 2003. Strontium as a marker for estimation of microscopic growth rates in a bivalve. Mar. Ecol. Prog. Ser. 257, 295-301.

Galstoff, P.S., 1964. The American oyster, Crassostrea virginica Gmelin. U.S. Fish Wild. Serv. Fish Bull. 64, 67-74. 
523 Gangnery, A., Chariband, J.-M., Lagarde, F., La Gall, P., Oheix, J., Bacher, C., Buestel, D., 2003. Growth model of the Pacific oyster, Crassostrea gigas, cultured in Thau Lagoon (Méditerranée, France). Aquaculture 215, 267-290.

Gillikin, D.P., Lorrain, A., Navez, J., Taylor, J.W., André, L., Keppens, E., Baeyens, W., Dehairs, F., 2005. Strong biological controls on $\mathrm{Sr} / \mathrm{Ca}$ ratios in aragonitic marine bivalve shells. Geochem. Geophys. Geosyst. 6, 1-16.

Goodwin, D.H., Flessa, K.W., Schöne, B.R., Dettman, D.L., 2001. Cross-Calibration of Daily Growth Increments, Stable Isotope Variation, and Temperature in the Gulf of California Bivalve Mollusk Chione cortezi: Implications for Paleoenvironmental Analysis. Palaios 16, 387-398.

Götte, T., Richter, D.K., 2009. Quantitative aspects of Mn-activated cathodoluminescence of natural and synthetic aragonite. Sedimentology 56, 483-492.

Hawkes, G.P., Day, R.W., Wallace, M.W., Nugent, K.W., Bettiol, A.A., Jamieson, D.N., 1996. Analysing the growth and form of molluscs shell layers in situ, by cathodoluminescence microscopy and Raman spectroscopy. J. Shellfish Res. 15, 659666.

Higuera-Ruiz, R., Elorza, J., 2004. Adaptacion morfologica y microestructural de Crassostrea $s p$. en zonas de bahia contaminadas de Cantabria. Estudio preliminar. Geogaceta 36, 147-150.

Higuera-Ruiz, R., Elorza, J., 2009. Biometric, microstructural, and high-resolution trace element studies in Crassostrea gigas of Cantabria (Bay of Biscay, Spain): Anthropogenic and seasonal influences. Estuarine Coastal Shelf Sci. 82, 201-213.

Hockett, D., Ingram, P., LeFurgey, A., 1997. Strontium and Manganese Uptake in the Barnacle Shell: Electron Probe Microanalysis Imaging to Attain Fine Temporal Resolution of Biomineralization Activity. Mar. Environ. Res. 43, 131-143. 
548 Hudson, J.H., Shinn, E.A., Halley, R.B., Lidz, B., 1976. Sclerochronology: a tool for 549 interpreting past environments. Geology 4, 361-364.

550 Hussenot, J., Buchet, V., 1998. Marais maritimes et aquaculture. Activités durables pour la préservation et l'exploitation des zones humides littorales. Quae, Versailles, 279 pp.

Jones, D.S., 1980. Annual cycle of shell growth increment formation in two continental shelf bivalves and its paleoecologic significance. Paleobiology 6, 331-340.

Jones, D.S., 1983. Sclerochronology: Reading the Record of the Molluscan Shell. Am. Sci. 71, 384-391.

Jones, D.S., Quitmyer, I.R., 1996. Marking Time with Bivalve Shells: Oxygen Isotopes and Season of Annual Increment Formation. Palaios 11, 340-346.

Jones, D.S., Arthur, M.A., Allards, D.J., 1989. Sclerochronological records of temperature and growth from shells of Mercenaria mercenaria from Narragansett Bay, Rhode Island. Mar. Biol. 102, 225-234.

Kaandorp, R.J.G., Vonhof, H.B., Del Busto, C., Wesselingh, F.P., Ganssen, G.M., Marmol,

Killingley, J.S., Berger, W.H., 1979. Stable Isotopes in a Mollusk Shell: Detection of Upwelling Events. Science 205, 186-188.

Kirby, M.X., 2001. Differences in growth rate and environment between Tertiary and A.E., Pittman, L.R., van Hinte, J.E., 2003. Seasonal stable isotope variations of the modern Amazonian freshwater bivalve Anondites trapesialis. Palaeogeogr., Palaeoclimatol., Palaeoecol. 194, 339-354. Quaternary Crassostrea oyster. Paleobiology 27, 84-103.

Kirby, M.X., Soniat, T.M., Spero, H.J., 1998. Stable Isotope Sclerochronology of Pleistocene and Recent Oyster Shells (Crassostrea virginica). Palaios 13, 560-569.

571 Kooijman, S., 2000. Dynamic energy and mass budgets in biological systems. Cambridge University Press, Cambridge, 424 p. pp. 
573 Langlet, D., 2002. Enregistrement haute fréquence des conditions environnementales par les tests de bivalves. Application des techniques de marquage, cathodoluminescence, et chimie à l'huître Crassostrea gigas de l'étang de Thau (Hérault, France). PhD Université UPMC-Paris 06, pp. 231.

Langlet, D., Alunno-Bruscia, M., Rafélis, M., Renard, M., Roux, M., Schein, E., Buestel, D., 2006. Experimental and natural manganese-induced cathodoluminescence in the shell of the Japanese oyster Crassostrea gigas (Thunberg, 1793) from Thau Lagoon (Hérault, France): ecological and environmental implications. Mar. Ecol. Prog. Ser. $317,143-156$.

Lartaud, F., 2007. Les fluctuations haute fréquence de l'environnement au cours des temps géologiques. Mise au point d'un modèle de référence actuel sur l'enregistrement des contrastes saisonniers dans l'Atlantique nord. PhD UPMC-Paris 06, pp. 336.

Lartaud, F., Langlet, D., de Rafelis, M., Emmanuel, L., Renard, M., 2006. Description of seasonal rythmicity in fossil osyter shells Crassostrea aginensis Tournouer, 1914 (Aquitanian) and Ostrea bellovacina Lamarck, 1806 (Thanetian). Cathodoluminescence and sclerochronological approaches. Geobios 39, 845-852.

Lartaud, F., Emmanuel, L., de Rafelis, M., Pouvreau, S., Renard, M., 2009. Influence of food supply on the $\delta^{13} \mathrm{C}$ signature of mollusc shells: implications for palaeoenvironmental reconstitutions. Geo-Mar Lett, DOI 10.1007/s00367-00009-00148-00364.

Lawrence, D.R., 1988. Oysters as geoarcheologic objects. Geoarcheology 3, 267-274.

Lazareth, C.E., Vander Putten, E., André, L., Dehairs, F., 2003. High-resolution trace element profiles in shells of the mangrove bivalve Isognomon ephippium: a record of environmental spatio-temporal variations? Estuarine Coastal and Shelf Science 57, $1103-1114$.

Lewis, D.E., Cerrato, R.M., 1997. Mya arenaria. Mar. Ecol. Prog. Ser. 158, 177-189. 
598 Lietard, C., Pierre, C., 2008. High-resolution isotopic records ( $\delta 180$ and $\delta 13 C)$ and cathodoluminescence study of lucinid shells from methane seeps of the Eastern Mediterranean. Geo-Mar. Lett. 28, 195-203.

601

602

603

604

605

606

607

608

609

610

611

612

613

614

615

616

617

618

619

620

621

Machel, H.G., Mason, R.A., Mariano, A.N., Mucci, A., 1991. Causes and emission of luminescence in calcite and dolomite, and their applicatins for studies of carbonates diagenesis. In: Barker, C.E., Kopp, O.C. (Eds.), Luminescence Microscopy: Quantitative and Qualitative aspects. SEPM, pp. 9-25.

Marchitto, T.M., Jones, G.A., Goodfriend, G.A., Weidman, C.R., 2000. Precise Temporal Corelation of Holocene Mollusk Shells Using Sclerochronology. Quatern. Res. 53, 236-246.

Markich, S.J., Jeffree, R.A., 1994. Absorption of divalent trace metals as analogues of calcium by Australian freshwater bivalves: an explanation of how water hardness reduces metal toxicity. Aquatic Toxicology 29, 257-290.

Meistertzheim, A.L., 2008. Capacité d'adaptation d'une espèce invasive, l'huître creuse du Pacifique Crassostrea gigas, en région Bretagne. PhD Université de Bretagne Occidentale, pp. 206.

Pirastru, L., 1994. The Bay of Bourgneuf underground salt water: physicochemical characteristics, bioavailability of phosphates and potential fertility for Skeletonema costatum (Grev.) Cleve. PhD Université de Nantes, pp. 234.

Pouvreau, S., Bourles, Y., Lefebvre, S., Gangnery, A., Alunno-Bruscia, M., 2006. Application of a dynamic energy budget model to the Pacific oyster Crassostrea gigas, reared under various environmental conditions. Journal of Sea Research 56, in press.

Richardson, C.A., 2001. Molluscs as archive of environmental change. Oceanography and Marine Biology - An Annual Review 39, 103-164. 
622 Richardson, C.A., Crisp, D.J., Runham, N.W., Gruffyd, L.D., 1980. The use of tidal growth bands in the shell of Cerastoderma edule to measure seasonal growth rates under cool temperate and sub-arctic conditions. Journal of the Marine Biological Association of the Uniteed Kingdom 60, 977-989.

Richardson, C.A., Collis, S.A., Ekaratne, K., Dare, P., Key, D., 1993. The age determination and growth rate of the European flat oyster, Ostrea edulis, in British waters determined from acetate peels of umbo growth lines. ICES J. Mar. Sci. 50, 493-500.

Richardson, C.A., Peharda, M., Kennedy, H., Kennedy, P., Onofri, V., 2004. Age, growth rate and season of recruitment of Pinna nobilis (L) in the Croatian Adriatic determined from Mg:Ca and Sr:Ca shell profiles. J. Exp. Mar. Biol. Ecol. 299, 1-16.

Roduit, N., 2006. JMicroVision: un logiciel d'analyse d'images pétrographiques polyvalent., Genève. PhD Université de Genève, pp. 128.

Samain, J.F., McCombie, H., 2007. Summer mortality of Pacific oyster Crassostrea gigas. Morest Program. Ifremer/Quae, Versailles, $332 \mathrm{pp}$.

Sato-Okoshi, W., Okoshi, K., 2002. Application of fluorescent substance to the analysis of growth performance in Antarctic bivalve, Laternula elliptica. Polar Biosci. 15, 66-74.

Schöne, B.R., Giere, O., 2005. Growth increments and stable isotope variation in shells of the deep-sea hydrothermal vent bivalve mollusk Bathymodiolus brevior from the North Fiji Basin, Pacific Ocean. Deep Sea Research 52, 1896-1910.

Schöne, B.R., Tanabe, K., Dettman, D.L., Sato, S., 2003. Environmental controls on shell growth rates and $\delta^{18} \mathrm{O}$ of the shallow-marine bivalve mollusk Phacosoma japonicum in Japan. Mar. Biol. 142, 473-485.

Schöne, B.R., Dunca, E., Mutvei, H., Norlund, U., 2004. A 217-year record of summer air temperature reconstructed from freshwater pearl mussels (M. margaritifera, Sweden). Quaternary Science Reviews 23, 1803-1816. 
647 Schöne, B.R., Lega, J., Flessa, K.W., Goodwin, D.H., Dettman, D.L., 2002. Reconstructing daily temperatures from growth rates of the intertidal bivalve mollusk Chione cortezi (northern Gulf of California, Mexico). Palaeogeogr., Palaeoclimatol., Palaeoecol. 184, 131-146.

Surge, D., Lohmann, K.C., Dettman, D.L., 2001. Controls on isotopic chemistry of the American oyster, Crassostrea virginica: implications for growth patterns. Palaeogeogr., Palaeoclimatol., Palaeoecol. 172, 283-296.

Tanabe, K., 1988. Age and growth rate determination of an intertidal bivalve, Phacosoma japonicum, using internal shell increment. Lethaia 21, 231-241.

Thébault, J., Chauvaud, L., Clavier, J., Fichez, R., Morize, E., 2006. Evidence of a 2-day periodicity of striae formation in the tropical scallop Comptopallium radula using calcein marking. Mar. Biol. 149, 257-267.

Vander Putten, E., Dehairs, F., Keppens, E., Baeyens, W., 2000. High resolution distribution of trace elements in the calcite shell layers of modern Mytilus edulis: Environmental and biological controls. Geochim. Cosmochim. Acta 64, 997-1011.

Verrecchia, E.P., 2004. Multiresolution analysis of shell growth increments to detect variations in natural cycles. In: Francus, P. (Ed.), Image Analysis, Sediments and Paleoenvironments. Kluwer Academic Publishers, Dordrecht, The Netherlands.

Wada, K., Fujinuki, T., 1976. Biomineralization in bivalve molluscs with emphasis on the chemical composition of the extrapallial fluid. In: Watabe, N., Wilbur, K.M. (Eds.), The Mechanisms of Mineralization in the Invertebrate and Plants. Univ S.C. Press, Columbia, pp. 175-190.

Wanamaker, A.D., Kreutz, K.J., Borns, H.W., Introne, D.S., Feindel, S., Funder, S., Rawson, P.D., Barber, B.J., 2007. Experimental determination of salinity, temperature, growth, and metabolic effects on shell isotope chemistry of Mytilus edulis collected from 
Maine and Greenland. Paleoceanography 22, 1-12, PA2217, doi:2210.1029/2006PA001352.

674 Wheeler, A.P., 1992. Phosphoproteins of oyster (Crassostrea virginica) shell organic matrix. In: Suga, S., Watabe, N. (Eds.), Hard tissue mineralization and demineralization. Springer-Verlag, Tokyo, pp. 171-187.

677 Witbaard, R., Jenness, M.I., van der Borg, K., Ganssen, G., 1994. Verification of annual growth increments in Arctica islandica L. from the North Sea by means of oxygen and carbon isotopes. Netherlands Journal Sea Research 33, 91-101.

680

681 
683

684

685

686

687 Table 2: Dates of $\mathrm{Mn}^{2+}$ markings of the oyster shells on each location. The dates in italic point 688 out the death of the samples.

689

690 Table 3: Description of four $\mathrm{Mn}^{2+}$ markings experiments conducted on C. gigas oyster shells.

691 The red arrows point out the marking lines on the shell section microphotographs (white scale 692 bar is $200 \mu \mathrm{m})$.

693

694 Table 4: Growth rates measurements of the hinge area from C. gigas marked oysters and 695 estimated shell mean annual growth rate using the relationships taken Fig. 7.

696

697 Table 5: Evolution of the environmental parameters (temperature, chlorophyll a and seawater 698 manganese content) at Baie des Veys during the breeding and marking-recapture period of 699 oyster shells.

700

701 
703

704 Figure 1: Simplified map showing the different locations where the oyster Crassostrea gigas 705

\section{Legends to Figures}

shells were transplanted and cultured. (1) Baie des Veys, (2) L'Houmeau marine pond, (3) Marennes-Oléron, (4) Arcachon basin and (Nur) nursery tanks located at Bouin.

Figure 2: A- Photograph of a left valve of the oyster C. gigas. B- Transmitted-light microphotograph of a thin-section of the hinge region showing the two characteristic microstructure of the oyster shells: foliated calcite (Fo) and chalky calcite (Ch). Cathodoluminescence analyses are performed exclusively on the foliated calcite of this area. $\mathrm{C}$ and D are BSE images with close ups of the two microstructure. Images are made with a ZEISS ULTRA 55VP SEM operating at $7.00 \mathrm{kV}$ on carbon-coated tin-section.

Figure 3: Age model of a $\mathrm{Mn}^{2+}$ marked C. gigas shell from Baie des Veys (Normandy). CL images are digitalized and successive chemical markings are identified on the resulting spectrum. Marking dates are then fitted with the breeding calendar. Linear growth rate is applied between two successive Mn-spikes.

Figure 4: Seasonal natural cathodoluminescence changes of juvenile $C$. gigas brood in Baiedes-Veys ( $a=$ BDVn6-2, b= BDVn6-4, c= BDVn6-5), L'Houmeau marine pond ( $d=$ Man6-4), Marennes-Oléron Bay ( $\mathrm{e}=$ Dajn6-4) and Arcachon basin $(\mathrm{f}=$ Tesjs6-2), recognized by the $\mathrm{Mn}^{2+}$ markings (black arrow). 
725 Figure 5: Seasonal natural cathodoluminescence changes of adult's $C$. gigas brood in

726 Marennes-Oléron Bay (a) and Arcachon basin (b), recognized by the $\mathrm{Mn}^{2+}$ markings (black 727 arrows).

728

729 Figure 6: Linear relationships observed between the hinge and the shell length from Thau $C$.

730 gigas shells (dotted line, after Langlet, 2002) and Baie des Veys shells (continuous line and 731 dots with error bars, this study).

732

733 Figure 7: Size at age date for shells from (A) Baie des Veys, (B) L'Houmeau marine pond,

734 (C) Marennes-Oléron bay and (D) Arcachon basin showing the estimated Von Bertalanffy 735 relationships for each location. The different symbols represent different individuals.

736

737 Figure 8: Seasonal variation in $C$ gigas hinge area growth rates. Each data point is the 738 calculated growth rate from an individual oyster between 2 dates of markings. (A) Baie des

739 Veys, (B) L’Houmeau marine pond, (C) Marennes-Oléron bay, and (D) Arcachon basin. 


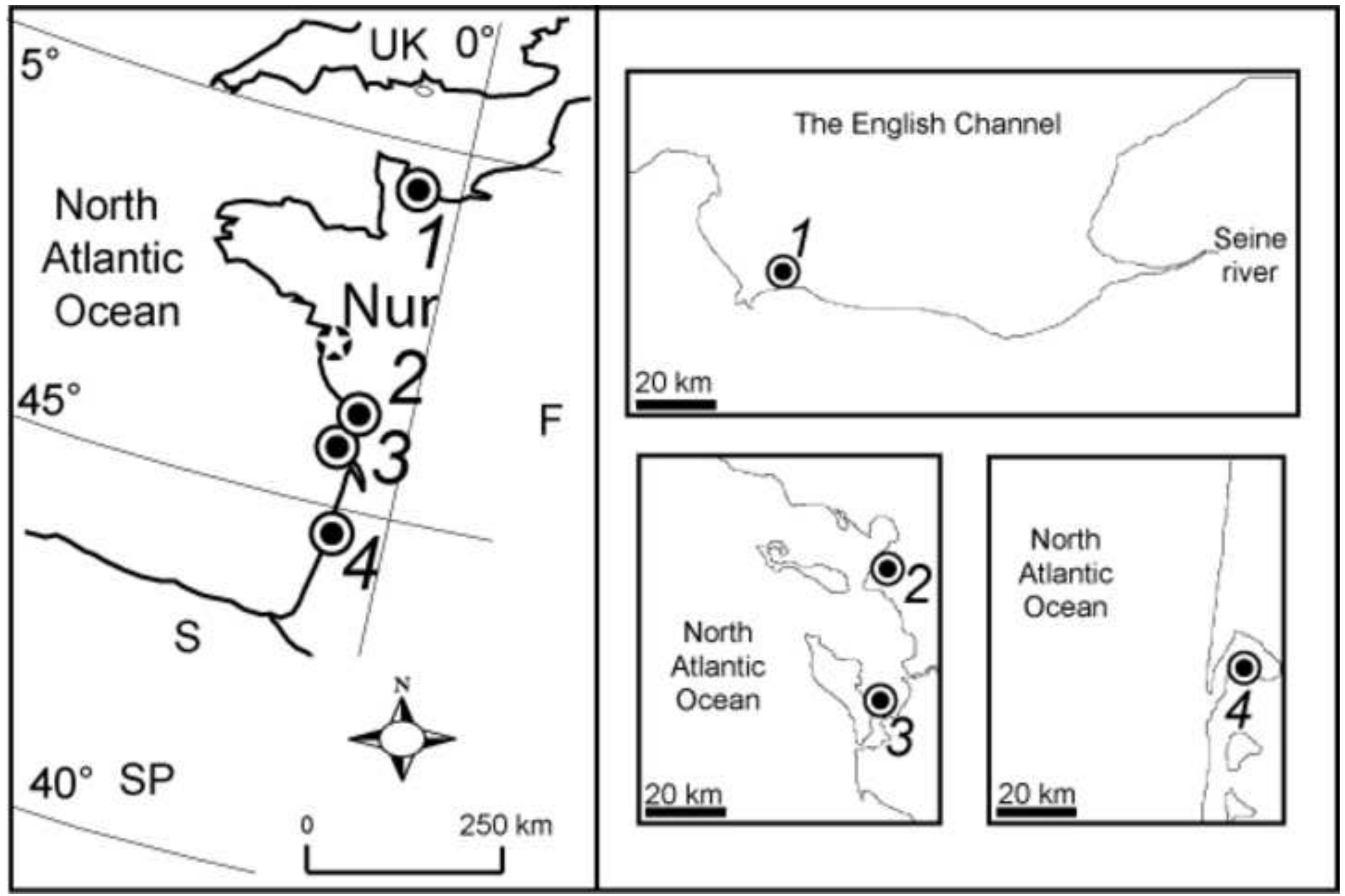


Click here to download high resolution image

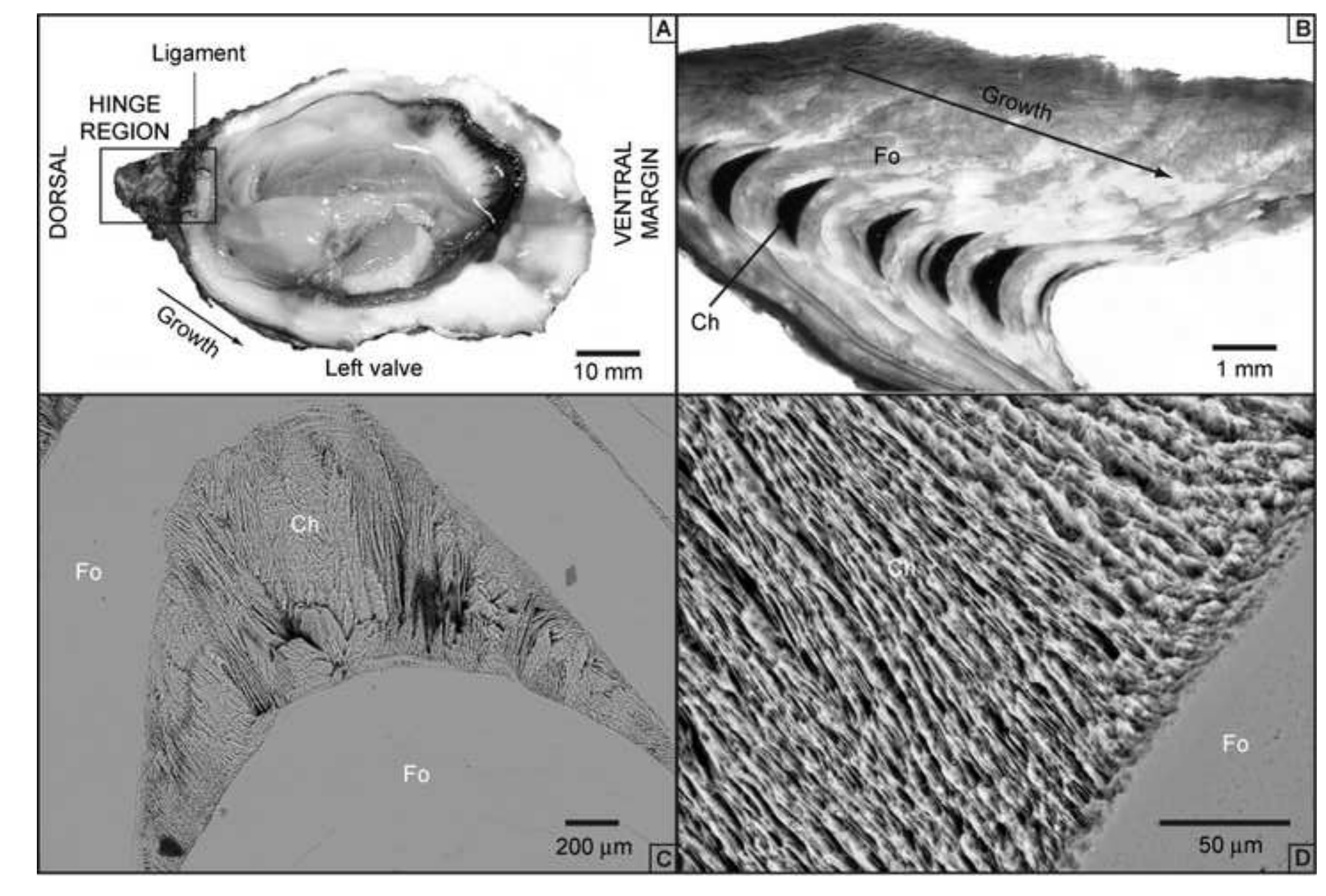




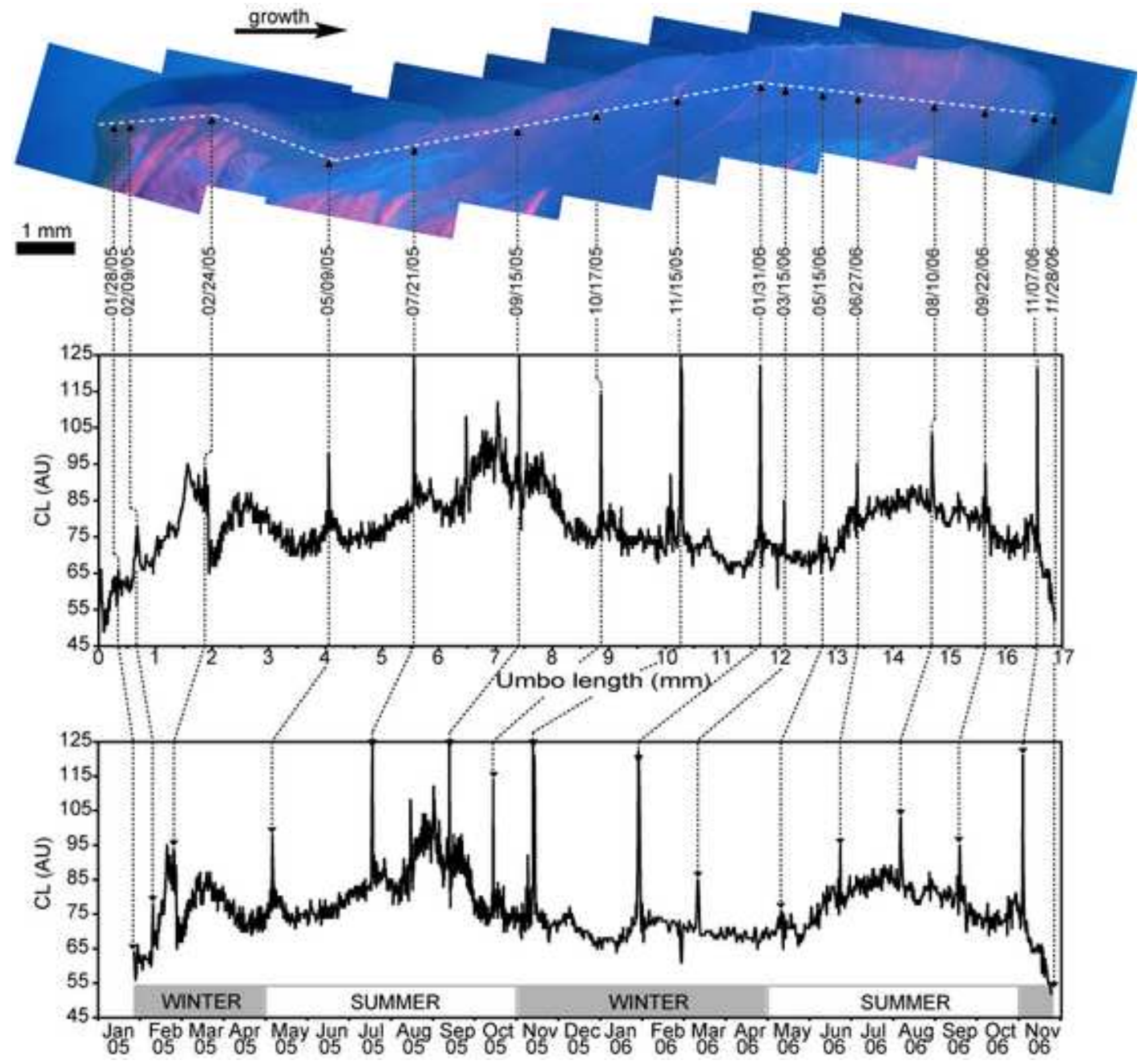



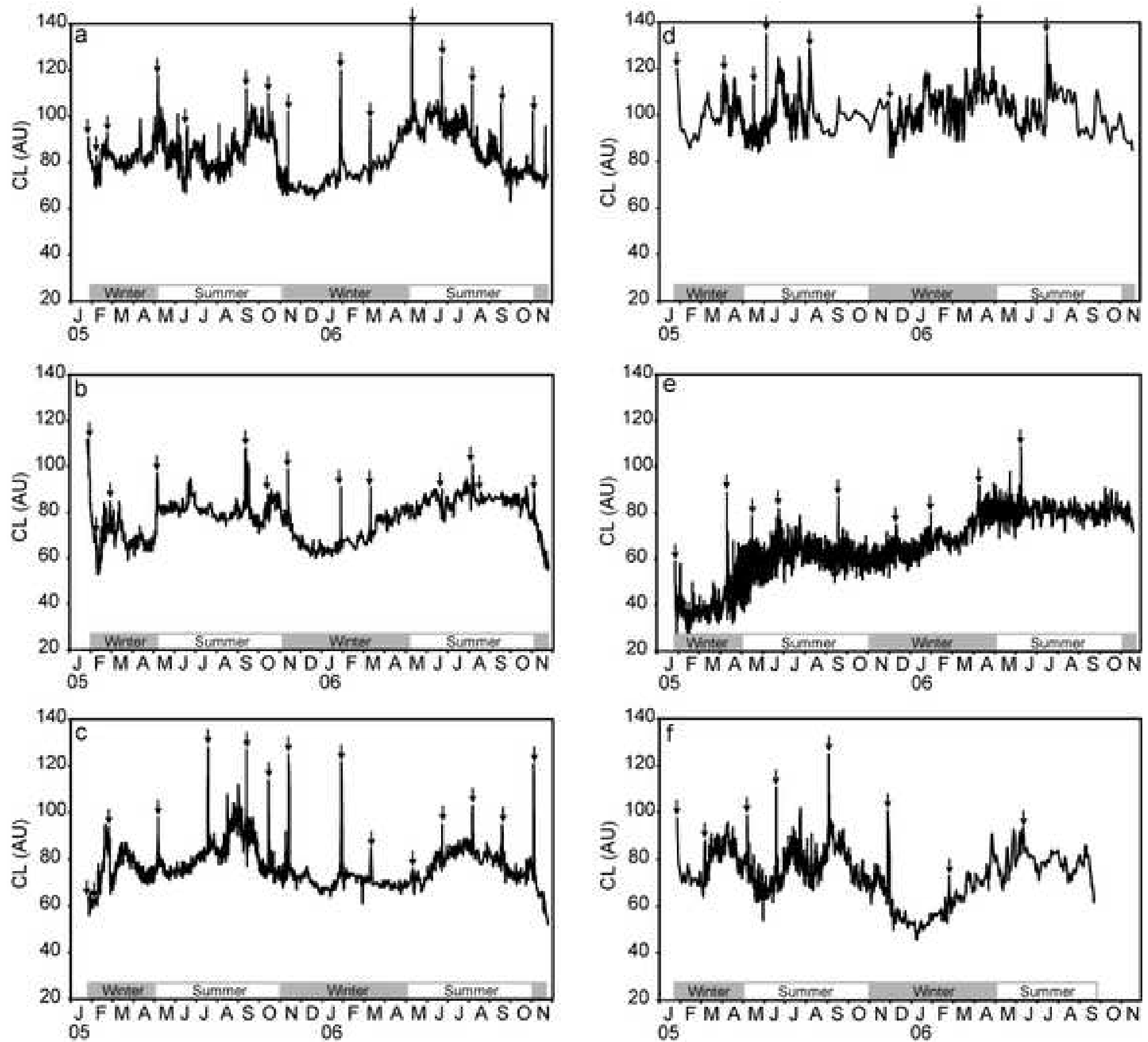

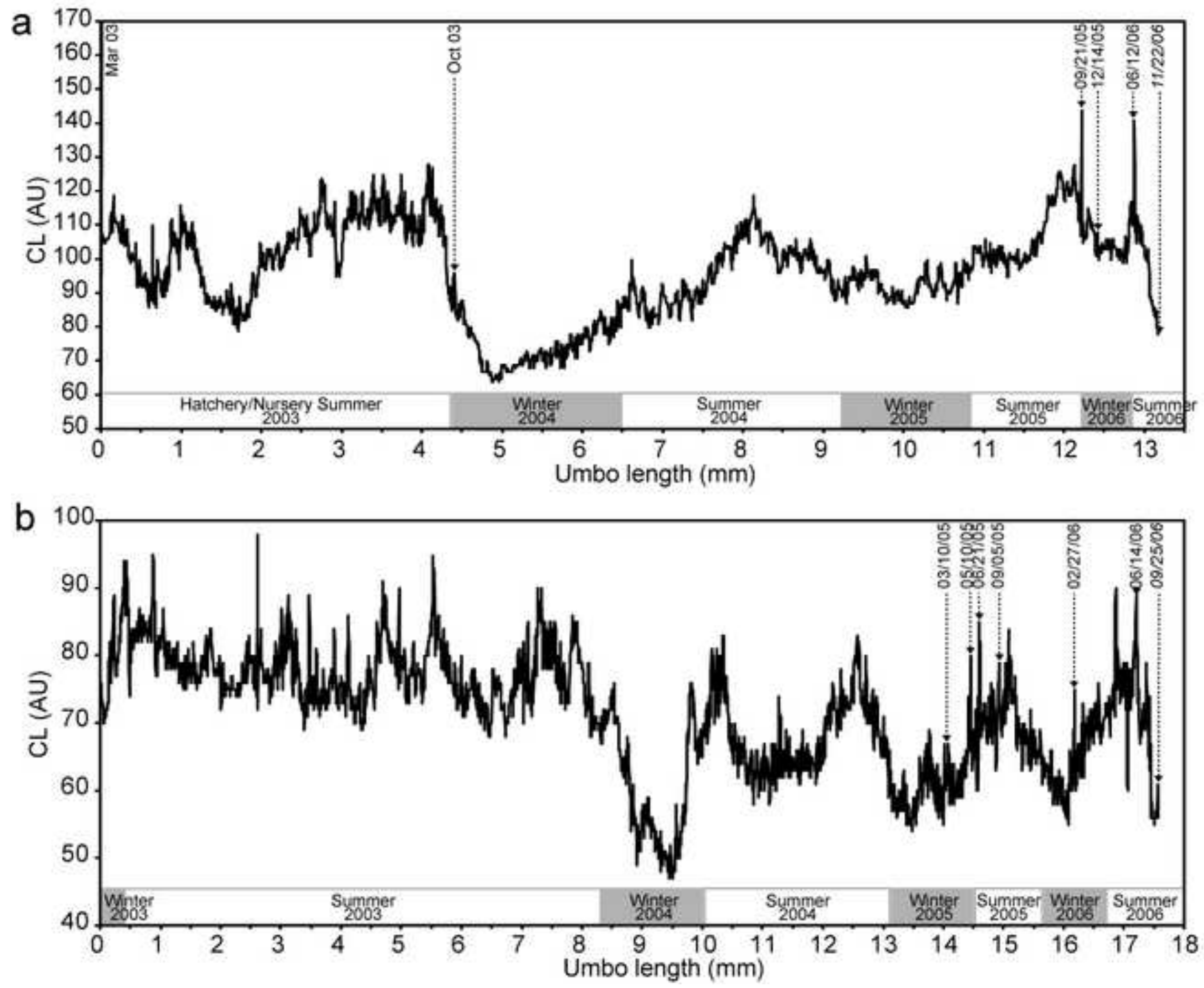


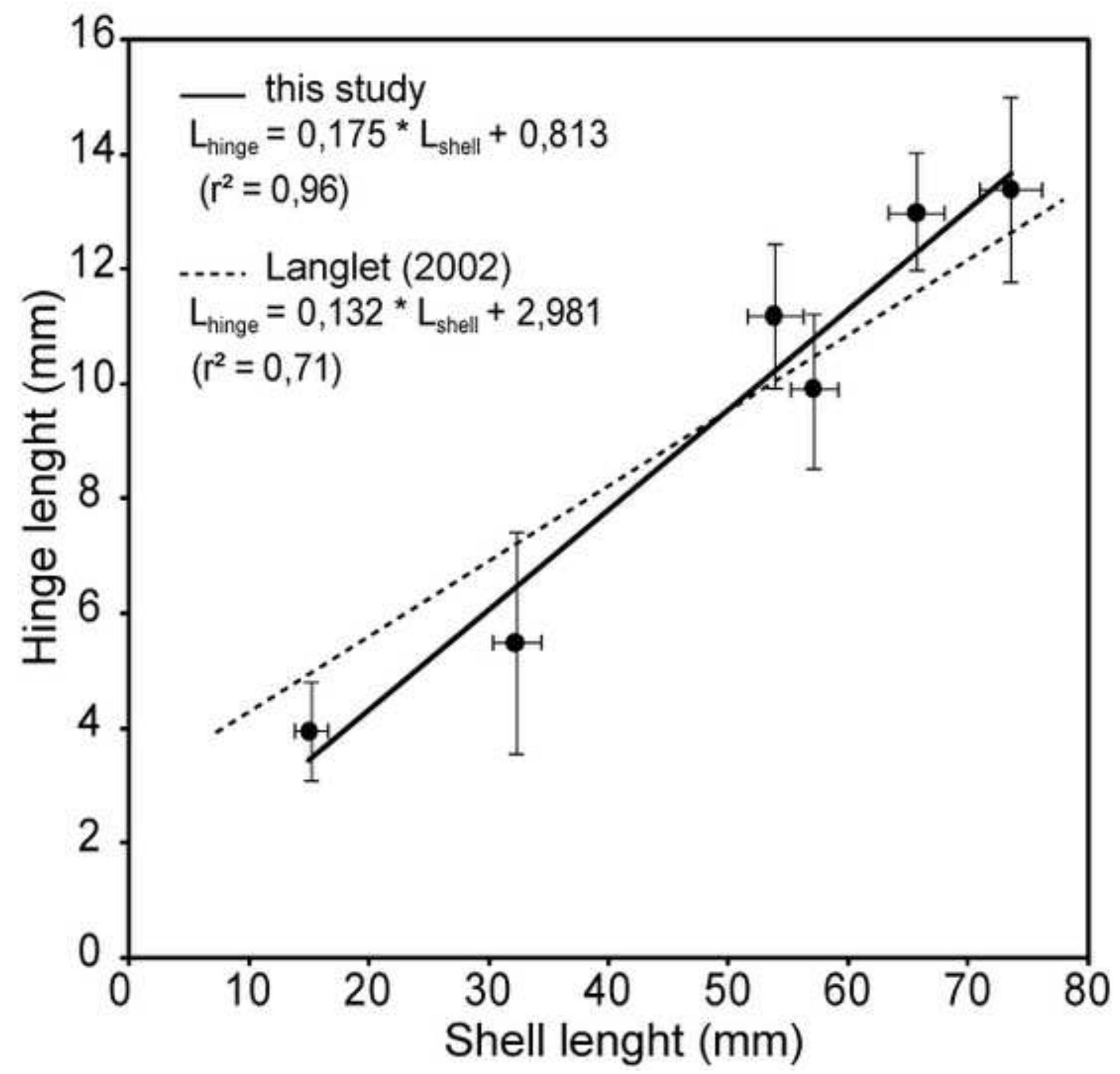



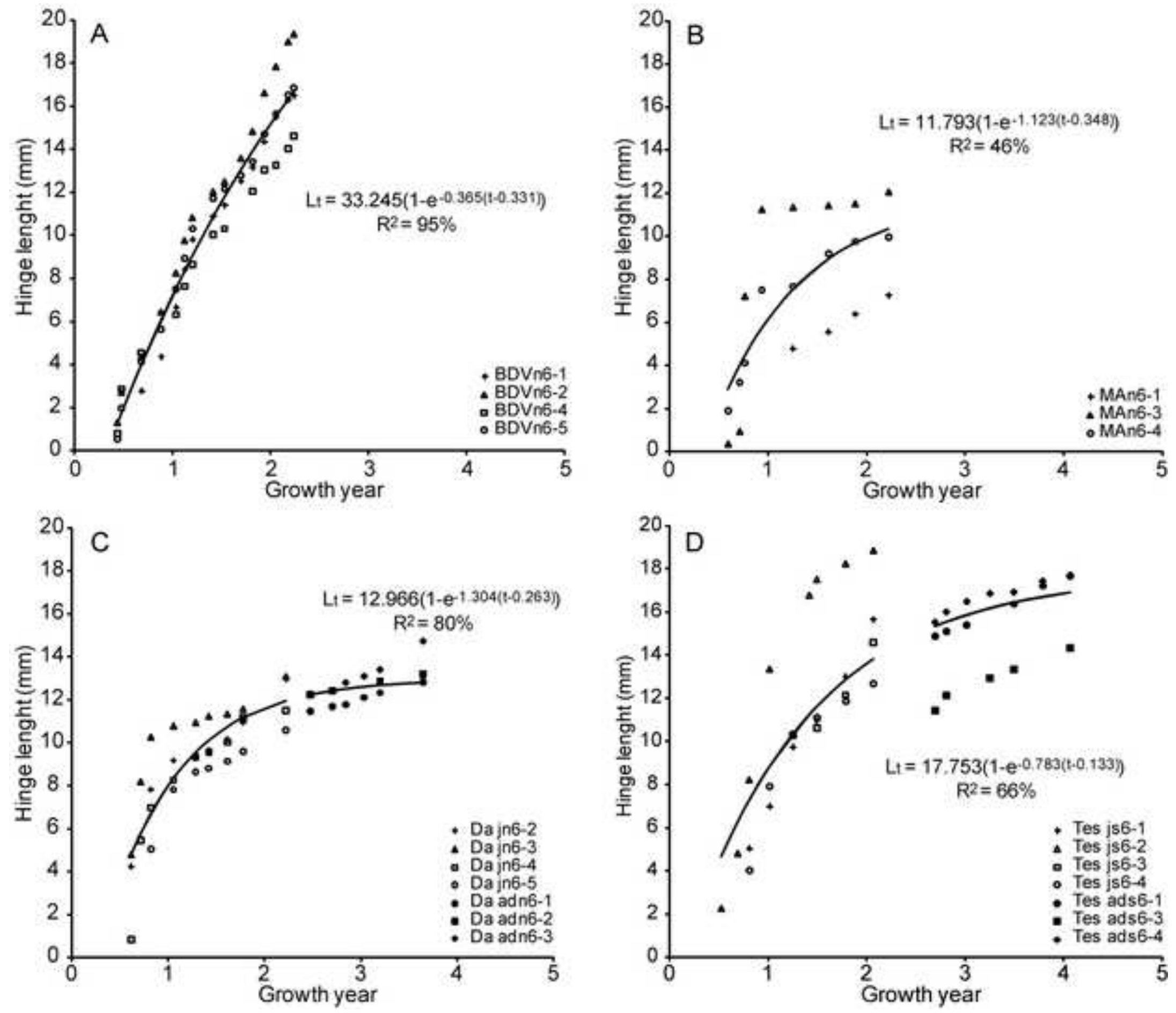

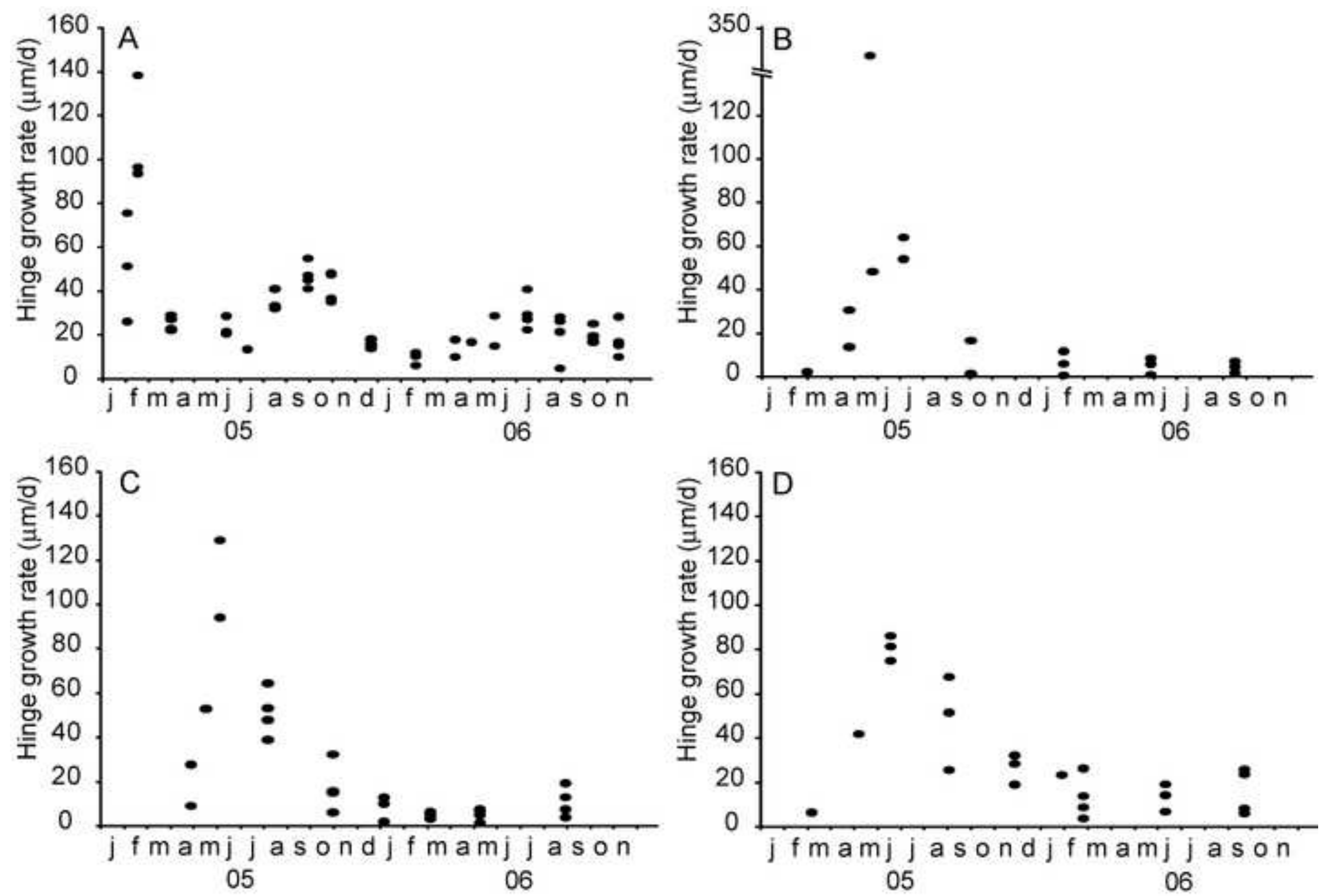


\begin{tabular}{|c|c|c|c|c|c|c|c|}
\hline Location & Shells & Birth & $\begin{array}{c}\text { Hatchery (La } \\
\text { Tremblade) + } \\
\text { Nursery (Bouin) }\end{array}$ & $\begin{array}{l}\text { Oyster tables } \\
\text { (before the } \\
\text { marking phase) }\end{array}$ & $\begin{array}{l}\text { Marine } \\
\text { ponds }\end{array}$ & $\begin{array}{l}\text { Oyster tables } \\
\text { (during the } \\
\text { marking phase) }\end{array}$ & $\begin{array}{l}\text { Collection of } \\
\text { oysters }\end{array}$ \\
\hline Baie-des-Veys (Géfosse) & C. gigas (juvenile) & summer 04 & & & & Feb 05 & Nov 06 \\
\hline $\begin{array}{l}\text { L'Houmeau marine pond } \\
\quad \text { (Marais du plomb) }\end{array}$ & C. gigas (juvenile) & summer 04 & & & Feb 05 & & Nov 06 \\
\hline \multirow{2}{*}{$\begin{array}{l}\text { Marennes-Oléron bay } \\
\text { (d'Agnas) }\end{array}$} & C. gigas (juvenile) & summer 04 & & & & Feb 05 & Nov 06 \\
\hline & C. gigas (adult) & Mar 03 & Mar 03 & Oct 03 & Jun 05 & Sept 05 & Nov 06 \\
\hline \multirow{2}{*}{ Arcachon basin (Tès) } & C. gigas (juvenile) & summer 04 & & & & Feb 05 & Sept 06 \\
\hline & C. gigas (adult) & summer 02 & & Feb 03 & & Feb 05 & Sept 06 \\
\hline
\end{tabular}




\begin{tabular}{|c|c|c|c|c|c|}
\hline \multirow{2}{*}{$\begin{array}{c}\begin{array}{c}\text { Baie-des-Veys } \\
\text { (Géfosse) }\end{array} \\
\text { juvenile }\end{array}$} & \multirow{2}{*}{$\begin{array}{c}\begin{array}{c}\text { L'Houmeau (Marais } \\
\text { du Plomb) }\end{array} \\
\text { juvenile }\end{array}$} & \multicolumn{2}{|c|}{ Marennes-Oléron bay (d'Agnas) } & \multicolumn{2}{|c|}{ Arcachon basin (Tes) } \\
\hline & & juvenile & adult & juvenile & adult \\
\hline $1 / 28 / 2005$ & $1 / 28 / 2005$ & $1 / 28 / 2005$ & & $1 / 28 / 2005$ & \\
\hline $2 / 9 / 2005$ & $4 / 6 / 2005$ & $4 / 13 / 2005$ & & $3 / 10 / 2005$ & $3 / 10 / 2005$ \\
\hline $2 / 24 / 2005$ & $5 / 19 / 2005$ & $5 / 19 / 2005$ & & $5 / 10 / 2005$ & $5 / 10 / 2005$ \\
\hline $5 / 9 / 2005$ & $6 / 7 / 2005$ & $6 / 27 / 2005$ & & $6 / 21 / 2005$ & $6 / 21 / 2005$ \\
\hline $7 / 21 / 2005$ & $8 / 9 / 2005$ & $9 / 21 / 2005$ & $9 / 21 / 2005$ & $9 / 5 / 2005$ & $9 / 5 / 2005$ \\
\hline $9 / 15 / 2005$ & $12 / 2 / 2005$ & $12 / 14 / 2005$ & $12 / 14 / 2005$ & $11 / 30 / 2005$ & $11 / 30 / 2005$ \\
\hline $10 / 17 / 2005$ & $4 / 12 / 2006$ & $2 / 2 / 2006$ & $2 / 2 / 2006$ & $2 / 27 / 2006$ & $2 / 27 / 2006$ \\
\hline $11 / 15 / 2005$ & $7 / 20 / 2006$ & $4 / 13 / 2006$ & $4 / 13 / 2006$ & $6 / 14 / 2006$ & $6 / 14 / 2006$ \\
\hline $1 / 31 / 2006$ & $11 / 21 / 2006$ & $6 / 12 / 2006$ & $6 / 12 / 2006$ & $9 / 25 / 2006$ & $9 / 25 / 2006$ \\
\hline $3 / 15 / 2006$ & & $11 / 22 / 2006$ & $11 / 22 / 2006$ & & \\
\hline \multicolumn{6}{|l|}{$5 / 15 / 2006$} \\
\hline \multicolumn{6}{|l|}{$6 / 27 / 2006$} \\
\hline \multicolumn{6}{|l|}{$8 / 10 / 2006$} \\
\hline \multicolumn{6}{|l|}{$9 / 22 / 2006$} \\
\hline \multicolumn{6}{|l|}{$11 / 7 / 2006$} \\
\hline $11 / 28 / 2006$ & & & & & \\
\hline
\end{tabular}


Table 3

\begin{tabular}{|c|c|c|c|c|c|}
\hline $\begin{array}{l}\text { Immersion } \\
\text { time }\end{array}$ & $\begin{array}{l}\mathrm{MnCl}_{2}, 4 \mathrm{H}_{2} \mathrm{O} \\
\text { concentration }\end{array}$ & $\begin{array}{l}\text { Cold cathod } \\
\text { adjustment }\end{array}$ & $\begin{array}{c}\text { Exposure } \\
\text { time }\end{array}$ & $\begin{array}{l}\text { Quality of } \\
\text { mark }\end{array}$ & Incorporated mark \\
\hline $4 \mathrm{~h}$ & $90 \mathrm{mg} . \mathrm{l}^{-1}$ & $\begin{array}{c}18 \mathrm{kV} \\
280 \mu \mathrm{A} \cdot \mathrm{mm}^{-2}\end{array}$ & $10 \mathrm{~s}$ & Clear mark & \\
\hline $1 \mathrm{~h} 30$ & 120 mg.l-1 & $\begin{array}{c}15 \mathrm{kV} \\
300 \mu \mathrm{A} \cdot \mathrm{mm}^{-2}\end{array}$ & $30 \mathrm{~s}$ & Clear mark & \\
\hline $1 \mathrm{~h}$ & 120 mg.l-1 & $\begin{array}{c}17 \mathrm{kV} \\
180 \mu \mathrm{A} \cdot \mathrm{mm}^{-2}\end{array}$ & $30 \mathrm{~s}$ & Clear mark & \\
\hline $30 \mathrm{~min}$ & 120 mg.l-1 & $\begin{array}{c}17 \mathrm{kV} \\
190 \mu \mathrm{A} \cdot \mathrm{mm}^{-2}\end{array}$ & $30 \mathrm{~s}$ & Faint mark & \\
\hline
\end{tabular}




\begin{tabular}{|c|c|c|c|c|}
\hline & $\begin{array}{l}\text { Nb of } \\
\text { shells }\end{array}$ & $\begin{array}{l}\text { Year of } \\
\text { growth }\end{array}$ & $\begin{array}{c}\text { Measured mean } \\
\text { hinge growth rate } \\
(\mu \mathrm{m} / \mathrm{d})\end{array}$ & $\begin{array}{c}\text { Estimated mean } \\
\text { shell growth rate } \\
(\mathrm{mm} / \mathrm{yr})\end{array}$ \\
\hline \multirow[t]{2}{*}{ Baie des Veys } & 4 & 1st & 44 & 87 \\
\hline & & $2 n d$ & 19 & 35 \\
\hline \multirow[t]{2}{*}{ L'Houmeau marine pond } & 3 & $1 \mathrm{st}$ & 51 & 102 \\
\hline & & 2nd & 5 & 6 \\
\hline \multirow[t]{2}{*}{ Marennes-Oléron } & 4 & $1 s t$ & 36 & 70 \\
\hline & & $2 n d$ & 7 & 10 \\
\hline \multirow[t]{2}{*}{ Tès } & 4 & $1 s t$ & 47 & 93 \\
\hline & & $2 n d$ & 17 & 31 \\
\hline Marennes-Oléron (adults) & 3 & 4th & 4 & 4 \\
\hline \multirow[t]{2}{*}{ Tès (adults) } & 3 & 3th & 7 & 10 \\
\hline & & $4 \mathrm{~h}$ & 4 & 4 \\
\hline
\end{tabular}




\begin{tabular}{cccc}
\hline Marking dates & $\begin{array}{c}\text { Mean } \\
\text { temperature } \\
\left({ }^{\circ} \mathrm{C}\right)\end{array}$ & $\begin{array}{c}\text { Mean } \\
\text { chlorophyll a } \\
\left(\mu \mathrm{\mu g} \mathrm{I}^{-1}\right)\end{array}$ & $\begin{array}{c}\text { Mean } \mathrm{Mn}_{\text {water }} \\
\left(\mathrm{mg}^{\left.-I^{-1}\right)}\right.\end{array}$ \\
\hline $1 / 28 / 05-2 / 9 / 05$ & $7.4 \pm 0.3$ & & \\
2/9/05 - 2/24/05 & $7.0 \pm 0.5$ & 7.0 & \\
$2 / 24 / 05-5 / 9 / 05$ & $8.1 \pm 0.6$ & 2.0 & 0.0106 \\
$5 / 9 / 05-7 / 21 / 05$ & $15.3 \pm 0.5$ & 6.0 & 0.0076 \\
$7 / 21 / 05-9 / 15 / 05$ & $19.1 \pm 0.1$ & 1.3 & 0.0043 \\
$9 / 15 / 05-10 / 17 / 05$ & $17.2 \pm 0.3$ & 4.0 & 0.0260 \\
$10 / 17 / 05-11 / 15 / 05$ & $15.4 \pm 0.4$ & 1.9 & \\
$11 / 15 / 05-1 / 31 / 05$ & $9.2 \pm 0.6$ & 0.7 & 0.0122 \\
$1 / 31 / 05-3 / 15 / 06$ & $6.0 \pm 0.1$ & 0.9 & 0.0063 \\
$3 / 15 / 06-5 / 15 / 06$ & $8.6 \pm 0.5$ & 5.2 & 0.0129 \\
$5 / 15 / 06-6 / 27 / 06$ & $14.4 \pm 0.5$ & 3.1 & 0.0108 \\
$6 / 27 / 06-8 / 10 / 06$ & $18.8 \pm 0.4$ & 3.0 & 0.0075 \\
$8 / 10 / 06-9 / 22 / 06$ & $18.6 \pm 0.1$ & 2.0 & \\
$9 / 22 / 06-11 / 7 / 06$ & $16.8 \pm 0.4$ & 3.5 & \\
$11 / 7 / 06-11 / 28 / 06$ & $13.0 \pm 0.3$ & 0.6 & \\
\hline
\end{tabular}

